\title{
Editorial: 52nd annual meeting of the Brazilian Dental Materials Group
}

Rafael R. Moraes*

\author{
*Correspondence: \\ moraesrr@gmail.com \\ School of Dentistry, Federal \\ University of Pelotas, Rua \\ Gonçalves Chaves 457, room \\ 505, Pelotas, RS 96015-560, \\ Brazil
}

The 52nd annual meeting of the Brazilian Dental Materials Group, known by its acronym in Portuguese GBMD (Grupo Brasileiro de Materiais Dentários), was held in Uberlândia, Minas Gerais state, Brazil between July 19-22, 2016. The conference was chaired by the School of Dentistry from Federal University of Uberlândia. In total, 9 researchers lectured, 258 research posters were presented, and above 350 attendees participated in the meeting. The conference addressed significant issues related to dental biomaterials, including tools used for in vitro investigation and the clinical applicability of dental materials and techniques. Several researchers, including many undergraduate students, had the opportunity to share and discuss their research findings with the GBMD community and with experienced investigators.

The oral speakers presented the following lectures during the meeting: "CAD-CAM restorations: scientific evidence and clinical performance" by Prof. Flávio Neves (UFU); "Strategies to stabilize the resin-dentin bonds" by Prof. Josimeri Hebling (UNESP-Araraquara); "Anatomy of root canals and evaluation of endodontic materials" by Prof. Manoel Sousa Neto (USP-Ribeirão Preto); "Laboratory testing of dental adhesives and its clinical relevance" by Prof. Steve Armstrong (University of Iowa College of Dentistry, USA); "Technology applied to the scientific investigation of dental materials" by Prof. Marcelo Giannini (UNICAMP-Piracicaba); "Longevity of dental restorations in anterior and posterior teeth" by Prof. Flávio Demarco (UFPel); "Use of thio-urethane additives to reduce polymerization shrinkage and improve conversion in composites" by Prof. André Faria e Silva (UFS); "Improving light-curing instruction in dental school" by Prof. Richard Price (School of Biomedical Engineering, Dalhousie University, Canada); and "Fractography studies applied to restorative materials” by Prof. Paulo Cesar (USP-São Paulo).

This special issue of Applied Adhesion Science contains peer-reviewed papers submitted through the journal online submission system. The articles address relevant issues concerning the adhesive dentistry, including methods to age the bonded dentin interfaces, novel polymerization promoters for dental adhesives, and bonding to dental ceramics and root canal walls. This issue is the Fourth Special Issue with papers selected from GBMD meetings published in Applied Adhesion Science. I am delighted to share that the journal has been recently accepted for inclusion in the Scopus database, which hopefully will increase the readership of the journal and aid in consolidating the name of the journal as well as of the GBMD in the international research community.

(c) The Author(s) 2017. This article is distributed under the terms of the Creative Commons Attribution 4.0 International License (http://creativecommons.org/licenses/by/4.0/), which permits unrestricted use, distribution, and reproduction in any medium, provided you give appropriate credit to the original author(s) and the source, provide a link to the Creative Commons license, and indicate if changes were made. 


\section{Acknowledgements}

The organizing committee of the 52nd GBMD meeting thanks the sponsors and all colleagues who helped to organize the conference. We also thank to the researchers who served as reviewers for the articles published in this Special Issue.

\section{Publisher's Note}

Springer Nature remains neutral with regard to jurisdictional claims in published maps and institutional affiliations.

Received: 6 June 2017 Accepted: 6 June 2017

Published online: 09 June 2017

Submit your manuscript to a SpringerOpen ${ }^{\circ}$ journal and benefit from:

- Convenient online submission

\section{Rigorous peer review}

- Immediate publication on acceptance

Open access: articles freely available online

- High visibility within the field

- Retaining the copyright to your article

Submit your next manuscript at $\boldsymbol{\nabla}$ springeropen.com 